PR03 Smanjenje stigme prema oboljelima od shizofrenije među studentima medicine

Mirta Peček ${ }^{\mathrm{a}}$, Jelena Rakić Matićb, Marijana Peček Vidakovićc

${ }^{a}$ Medicinski fakultet, Sveučilište u Zagrebu

${ }^{\text {b }}$ Specijalistička ordinacija obiteljske medicine DZ Zagreb Zapad

c Specijalistička ordinacija obiteljske medicine Marijana Peček Vidaković, dr.med.,spec.obiteljske medicine

DOI: https://doi.org/10.26800/LV-143-supl3-PR03

Mirta Peček (0000-0003-4350-4025), Jelena Rakić Matić (0000-0001-9997-8989), Marijana Peček Vidaković (0000-0001-7892-2900)

Ključne riječi: stigmatizacija, shizofrenija, studenti medicine

Uvod/Cilj: Shizofrenija je kompleksni sindrom nepoznate etiologije, no smatra se da interakcija između gena i okolišnih čimbenika može uzrokovati razvoj shizofrenije. Stigma prema pacijentima kojima je dijagnosticirana shizofrenija predstavlja veliki društveni problem te su uočeni negativni stavovi studenata medicine o oboljelima. Glavni potencijalni razlozi za to su što studenti smatraju da nemaju dovoljno znanja o shizofreniji i nedostatak kontakta s pacijentima oboljelima od shizofrenije. Cilj je ovog rada procijeniti dostupne podatke o negativnim stavovima studenata medicine o oboljelima od shizofrenije i saznati kako možemo smanjiti stigmu.

Materijali i metode: Pretraživana je bibliografska baza podataka PubMed koristeći sljedeće pojmove: "stigmatization", "schizophrenia", "medical students".

Rezultati: Prema dostupnim istraživanjima, na pojavnost manje stigme prema oboljelima značajno utječe prisutnost mentalne bolesti u osobnoj anamnezi, kao i poznavanje osobe koja je oboljela. Povezivanje etiologije shizofrenije isključivo s genetskim čimbenicima češće je uključivalo stigmatizirajuće stavove. Studenti medicine koji su sudjelovali u kliničkim programima, koji se sastoje od edukacije i više kontakta s oboljelima od shizofrenije, imali su u konačnici pozitivnije stavove. Pronađene su i određene razlike među državama u kojima su se provodila ovakva istraživanja. Psihijatri su, uspoređujući sa studentima medicine, imali manje stigmatizirajuće stavove. Međutim, još je uvijek nedovoljno istraživanja koja bi utvrdila dugoročni učinak ovakvih antistigma programa na stavove studenata medicine.

Zaključak: Uvođenje antistigma programa u kurikulume medicinskih fakulteta, ne samo na jednoj godini studija, već tijekom cijelog školovanja, može imati pozitivan učinak na smanjenje stigme prema oboljelima od shizofrenije među studentima medicine. Psihijatri trebaju imati važnu ulogu u provođenju antistigma programa.

\title{
Reducing stigma towards patients diagnosed with schizophrenia among medical students
}

Keywords: stigmatization, schizophrenia, medical students

Introduction/Aim: Schizophrenia is a complex syndrome whose etiology is unknown, but it is thought that interaction between genes and a range of environmental factors may cause schizophrenia. Stigma against patients diagnosed with schizophrenia is a major social issue and there is evidence of negative attitudes among medical students towards people with schizophrenia. The perception of insufficient knowledge about schizophrenia and the lack of contact with patients might be major reasons for it. This review aimed to assess the data about the negative attitudes of medical students towards patients diagnosed with schizophrenia and find out how we can reduce the stigma.

Materials and methods: Electronic bibliographic database PubMed was searched for publications using the following keywords: "stigmatization", "schizophrenia", "medical students".

Results: Lower stigma was significantly associated with those with a history of mental illness diagnosis or having a relationship with someone experiencing one. A genetic explanation of schizophrenia was more frequently associated with stigmatizing attitudes. Medical students who had undergone clinical training which consists of education and more contact with patients had overall positive attitudes. Differences across countries were found. Psychiatrists presented lower levels of stigma compared with medical students. However, there is a limited number of published studies evaluating the long-term effects of antistigma training on attitudes of medical students.

Conclusion: Changing the curriculum of medical schools by integrating antistigma training, not only in particular years but also throughout the whole years of education could be beneficial to reduce the stigma among medical students. Psychiatrists should play an important role in antistigma training. 